\title{
PENGEMBANGAN MULTIMEDIA TUTORIAL BERFITUR PETA KONSEP UNTUK BELAJAR LAPISAN BUMI SISWA MTs
}

\author{
Moh. Dwi Handoko, Sulthoni, Saida \\ Jurusan Teknologi Pendidikan, Fakultas Ilmu Pendidikan, Universitas Negeri Malang \\ Jalan Semarang 5 Malang 65145 0341-574700 \\ handokodwi244@gmail.com
}

\section{Article History}

Received: 9 Juli 2020, Accepted: 30 November 2020, Published: 28 Mei 2021

\begin{abstract}
Abstrak
Multimedia tutorial lapisan bumi menjadi pelengkap dalam pembelajaran IPA di MTs Negeri 2 Nganjuk. Multimedia tutorial lapisan bumi didesain untuk menguatkan materi pelajaran IPA yang bersifat enrichment atau remidial dalam pembelajaran konvensional. Multimedia tutorial lapisan bumi adalah media pembelajaran yang dapat digunakan secara mandiri maupun kelompok yang memiliki fitur unggulan peta konsep untuk meningkatkan motivasi dan pemahaman belajar siswa. Tujuan pengembangan ini menghasilkan multimedia tutorial, serta mengetahui kelayakan dari multimedia yang dikembangkan. Model Penelitian ini menggunakan model Lee \& Owens. Hasil pengembangan Multimedia Tutorial Lapisan Bumi sebagai Komplemen Pembelajaran IPA berfitur Peta Konsep mendapatkan respon positif oleh ahli media dan ahli materi serta layak digunakan dan ada peningkatan hasil belajar.
\end{abstract}

Keyword: Multimedia; Tutorial; Lapisan Bumi; Peta Konsep

\begin{abstract}
Multimedia tutorials on earth layers become complementary in science learning and teaching at MTs Negeri 2 Nganjuk. Earth layer multimedia tutorials are designed to enhance science subject materials which take role as enrichment or remedial in conventional learning. Earth layer multimedia tutorials are learning media that can be used independently or in groups with excellent concept maps to increase students motivation as well as comprehension. The purpose of this development is to produce multimedia tutorials, as well as to discover the validity of the developed multimedia. This research model uses Lee \& Owens. The results of the development of the Earth Layer Multimedia Tutorial as a complement to science learning with the concept map feature received positive responses from media and material experts and was feasible to use and there was an increase learning outcome.
\end{abstract}

Keyword: Put 3-5 your keywords here in Bahasa Indonesia; keywords separated by semicolon 


\section{PENDAHULUAN}

Inovasi dalam dunia pendidikan secara kontinyu terus berkembang. Pendidikan di indonesia telah berkembang secara pesat dengan intregrasi dengan dunia teknologi. Beberapa komponen kemajuan dalam bidang pendidikan dilaksanakan supaya bisa meningkatkan kualitas dan kuantitas dalam bidang pendidikan. Dengan kemajuan teknologi saat ini banyak media (alat bantu) yang sederhana sampai yang memiliki inovasi yang mengagumkan (Nikolawatin et al., 2019). Media pembelajaran memiliki jenis yang berbeda-beda yang dapat digunakan sesuai usia masing- masing siswa. Dengan kesesuaian usia tersebut mampu membuat daya tarik tersendiri bagi siswa (Suminar, D, 2019). Dalam kegiatan pembelajarann peran media menjadi perantara komunikasi secara langsung dengan pengguna (user) (Capuno et al., 2019).

Siswa MTs / SMP berada pada usia remaja pada umur 12-15 tahun, pada usia ini umumnya terjadi masa peralihan dimana dari kanak-kanak menuju kedewasaan yang ditandai dengan beberapa perubahan fisik dan psikis. Teori perkembangan kognitif yang digunakan oleh Piaget, siswa usia SMP/MTs berada pada kelompok tahap operasional formal. Tahap ini siswa mampu mengelola kemampuan berpikir abstrak, yakni memikirkan beberapa solusi alternative pemecahan masalah (Suyono \& Hariyanto, 2014). Kemampuan siswa untuk memahami pelajaran berbeda-beda, ada kelompok siswa yang cepat memahami materi (fast learner) dan ada yang perlu pengulangan belajar (slow learner).

Mata pelajaran yang ada di sekolah MTs/SMP salah satunya pelajaran IPA. Pelajaran IPA dalam beberapa bab berisi materi yang tidak bisa diberikan contoh secara langsung (abstrak). Diperlukan alat bantu pembelajaran yang sesuai untuk menyampaikan materi dengan tuntas. Secara garis besar Ilmu Pengetahuan Alam adalah Ilmu yang mempelajari tentang gejala alam dan proses yang ada didalamnya. Suatu hal yang berkaitan tentang Ilmu Pengtahuan Alam tidak akan lepas hubungannya dalam kehidupan kita (Kastawaningtyas, 2017). Untuk menyampaikan materi yang abstrak tersebut jika dilengkapi dengan multimedia dapat meningkatkan pemahaman belajarnya.

Multimedia tutorial adalah media yang berperan sangat efektif untuk menyajikan materi pembelajaran yang bersifat prosedural secara utuh kepada siswa melalui konsep mastery learning. Program model tutorial mempunyai struktur rangkaian program yang diawali dengan tampilan halaman orientasi, penyajian isi atau materi, latihan soal disertai respons, penilaian hasil latihan soal, selanjutnya pengulangan materi, dan yang terakhir yaitu penutup program (Alessi \& Trollip, 2001). Berikut ini adalah struktur umum dan alur multimedia tutorial :

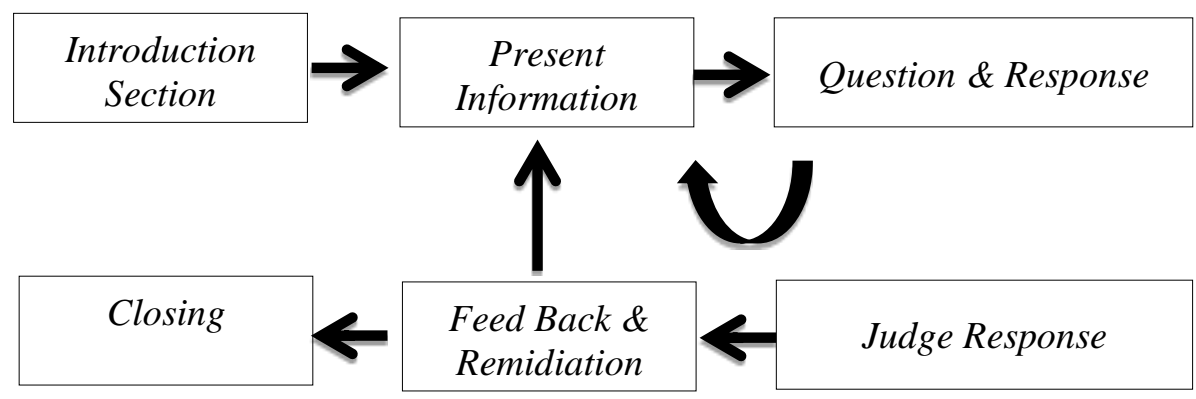

\section{Gambar 1. Struktur dan alur program multimedia tutorial (Alessi \& Trollip, 2001)}

Optimalisasi pembelajaran sangat diperlukan guna meningkatkan hasil belajar untuk mencapai tujuan pembelajaran. Jika dalam praktik pembelajaran kurang maksimal dan inovatif kemungkinan hasil belajar tidak meningkat bahkan dapat menjadikan siswa malas belajar. Dalam kegiatan observasi dan pengamatan di MTs Negeri 2 Nganjuk proses pembelajaran masih banyak menggunakan cara konvensional dan belum memanfaatkan teknologi sebagai alat bantu dalam proses pembelajaraan. 
Padahal di MTsN 2 Nganjuk difasilitasi laboratorium komputer dan $L C D$ Proyektor di setiap ruang kelas, dan para siswa kebanyakan juga telah mengusai komputer. Dalam proses pembelajaran IPA hanya sebatas menggunakan media power point dan modul saja, padahal didalam salah satu bab ada materi yang bersifat abstrak dan perlu pemahaman visualisasi. Guru mata pelajaran IPA di MTs Negeri 2 Nganjuk juga menyatakan bahwa sumber daya manusia di sekolah tersebut mampu menjalankan komputer dengan baik, namun kurang dalam hal pemanfaatan yang digunakan saat proses pembelajaran, serta belum ada tenaga pengembang Media Pembelajaran. Padahal murid di MTs Negeri 2 Nganjuk rata-rata siswa aktif, inovatif dan kreatif. Dalam proses pembelajaran kurikulum 2013 pembelajaran berpusat kepada siswa artinya siswa diwajibkan berperan aktif dalam setiap kegiatan pembelajaran (Anas et al., 2013). Jikalau dalam praktik kegiatan pembelajaran yang inovatif dan bersinergi dengan teknologi pasti siswa akan menjadi lebih antusias belajar dan tidak mudah bosan saat pembelajaran berlangsung.

Berdasarkan pernyataan di atas dapat diambil intisari bahwa dalam pembelajaran diperlukan sebuah media sebagai komplemen (pelengkap) yang dapat membantu siswa dalam memvisualisasikan dan menarasikan materi dengan tepat. Media yang tepat digunakan adalah multimedia tutorial, merupakan salah satu multimedia berbasis komputer yang dapat menarik perhatian siswa dan antusiasme siswa, serta mengoptimalkan pembelajaran serta dapat membantu guru untuk menuntaskan tujuan pembelajaran. Model tutorial menampilkan konten belajar terstruktur dari awal hingga akhir materi. Pembelajaran menggunakan multimedia tutorial membuat siswa menjadi lebih bersemangat dan lebih menarik, sehingga siswa termotivasi untuk semangat belajar lebih lanjut. Selain itu siswa dapat mempelajari kembali materi yang telah diperoleh dari guru (Khoerunisa, 2014). Hal tersebut diperkuat dengan penelitian Gama (2016) menunjukkan bahwa multimedia tutorial memperoleh kesimpulan layak sebagai media pembelajaraan atau berada di kualifikasi sangat baik serta mampu untuk meningkatkan hasil belajar siswa. Penelitian dari (Wardani et al., 2019) terbukti mampu meningkatkan hasil belajar dan antusiasme belajar Roudatul Ulum Karang Ploso.

Dalam mengembangkan multimedia tutorial lapisan bumi dilengkapi inovasi dengan fitur peta konsep. Peta konsep bisa digunakan siswa untuk merangkum suatu materi pelajaran. Selain itu peta konsep juga dapat digunakan untuk menyelidiki apa yang telah diketahui siswa, serta memberikan solusi yang efektif dan efisien untuk memahami materi baru (Arends, 1997). Hal tersebut sesuai dengan multimedia tutorial bahwa peta konsep dijadikan fitur evaluasi sumatif pada multimedia tutorial lapisan bumi. Disamping banyak kelebihan dari pembelajaran menggunakan peta konsep, ada juga hambatan siswa seperti siswa perlu mengetahui cara membuat peta, dan waktu yang lama membuat siswa bosan. Diperlukan penelitian tentang bagaimana menyederhanakan proses menyusun peta menjadi lebih efektif, mungkin melalui sistem online otomatis untuk membuat peta konsep (Collazo et al, 2015) atau pelatihan dalam menggunakan template yang sudah tersedia (Hilbert dan Renkl, 2009). Kopec, wood \& Brody (Asan: 2007) menjelaskan bahwa peta konsep digunakan variasi pembelajaran dalam pendidikan sains karena peta konsep dapat menolong guru dan siswa dalam mencerna pengetahuan dasar. Pendapat lain yang dijelaskan Kadir (2004), peta konsep yaitu suatu konsep yang saling berhubungan satu sama lain yang divisualisasikan dan berkaitan sebagai hasil dari pemetaan konsep.

\section{METODE}

Penelitian yang dilakukan ini adalah jenis penelitian pengembangan atau Research and Development (R\&D), yang bertujuan untuk mengembangkan suatu produk software berupa sumber belajar edukatif dengan aplikasi Multimedia Tutorial Lapisan Bumi sebagai Komplemen Pembelajaran IPA di MTs Negeri 2 Nganjuk.

Perbedaan penelitian dan pengembangan multimedia tutorial lapisan bumi sebagai komplemen matapelajaran IPA kelas VII di MTs Negeri 2 Nganjuk ini dengan penelitian sebelumnya terletak pada pemilihan materi (content), jenjang pendidikan dan inovasi yang berupa peta konsep, tampilan user 
interface \& user experience yang lebih interaktif. Software yang digunakan untuk pengembangan produk yaitu Lectora inspire versi 17, Adobe Flash CS 6, Adobe Photoshop CS 6, Corel Draw X8. Penelitian pengembangan ini meliputi rangkaian prosedural mulai dari analisis pengembangan, sampai uji coba produk. Model pengembangan yang digunakan dalam penelitian ini adalah model pengembangan Lee \& Owens (2004).

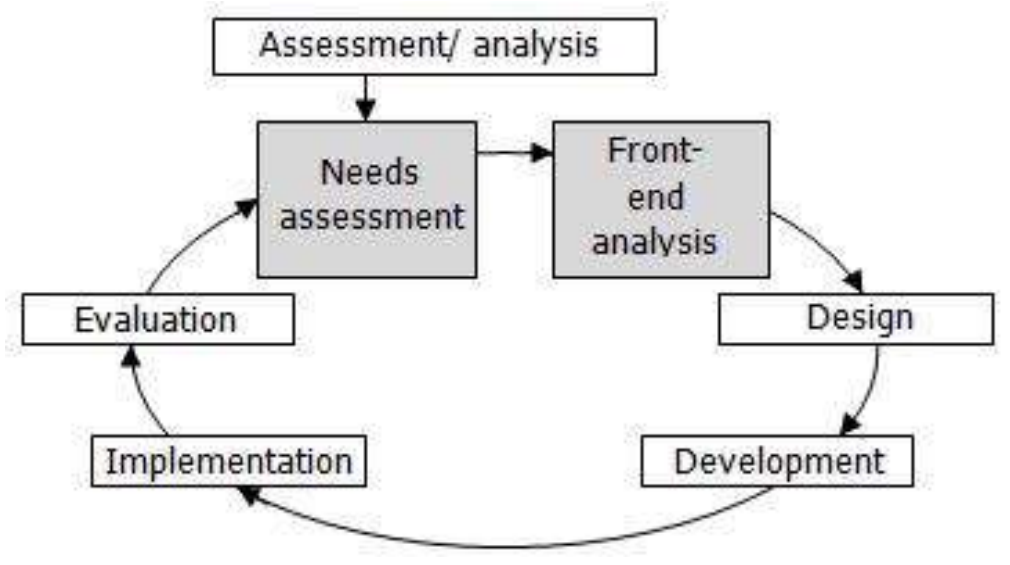

Gambar 2. Tahapan model Lee \& Owens (2004)

Tahapan pengembangan produk menurut William W. Lee \& Diana L. Owens yaitu Assessment, Design, Development, Implementation dan Evaluation. Namun pada penelitian ini hanya menggunakan 3 tahapan Analisis, Desain, dan Pengembangan. Pada Tahap Assessment/Analisis adalah tahap pertama yang terdiri dari Need Assasment dan Front End Analysis digunakan untuk mengumpulkan informasi dan data penting terkait masalah yang dihadapi di kelas dengan cara observasi dan wawancara. Tahap Design/Desain adalah tahapan perencanaan untuk merancang produk mulai dari membuat jadwal, perancangan butir materi, penyusunan naskah materi, pembuatan flowchart dan story board pada tahap desain alur multimedia mengacu pembelajaran pada metode multimedia tutorial (Allesi \& Trollip, 2001). Development/Pengembangan merupakan tahapan yang terdiri dari pra-produksi, produksi, postproduksi, dan review.

Subjek adalah siswa kelas VII di MTs Negeri 2 Nganjuk yang memperoleh pelajaran IPA bab Lapisan Bumi, namun saat uji coba lapangan hanya menggunakan uji kelompok kecil yang terdiri dari 3 siswa. Hal tersebut dilakukan karena saat penelitian semester genap tahun ajaran 2019/2020, bulan Januari-Mei 2020 bertepatan dengan terjadinya pandemi covid-19. Jenis data pada penelitian ini adalah data kuantitatif dan kualitatif. Data kuantitatif berupa penilaian terhadap produk media tutorial lapisan bumi yang dikembangkan berupa angket instrumen, dan data kualitatif diperoleh berupa kritik, saran dan komentar dari ahli materi dan media. Pengumpulan data dengan observasi dan angket, data observasi digunakan untuk mengetahui kondisi lapangan secara langsung, sedangkan angket instrumen digunakan untuk mendapatkan respon atau tanggapan media yang dikembangkan. Angket yang disajikan diberikan untuk ahli materi terdiri dari 30 butir pernyataan, 45 butir pernyataan untuk ahli media dan tanggapan siswa 20 butir pernyataan. Untuk membuktikan fitur peta konsep meningkatkan hasil belajar.

Penilaian angket menggunakan pengukuran rating scale 4 dengan rentangan nilai yang digunakan adalah 4,3,2,1. Angket respon yang telah terisi oleh para ahli dan siswa memberikan gambaran tentang kelayakan media yang dikembangkan. Proses perhitungan hasil belajar dilakukan oleh peneliti kepada 3 siswa MTs Negeri 2 Nganjuk dengan membandingkan nilai pretest dan postest. Jadi, sebelum menggunakan media pembelajaran multimedia lapisan bumi, siswa melakukan pretest dengan mengerjakan soal dan setelah menggunakan multimedia siswa melakukan postest. 


\section{HASIL}

Berikut adalah hasil yang diperoleh dari review angket dari ahli materi dan ahli media dan tangapan siswa pada multimedia tutorial lapisan bumi .

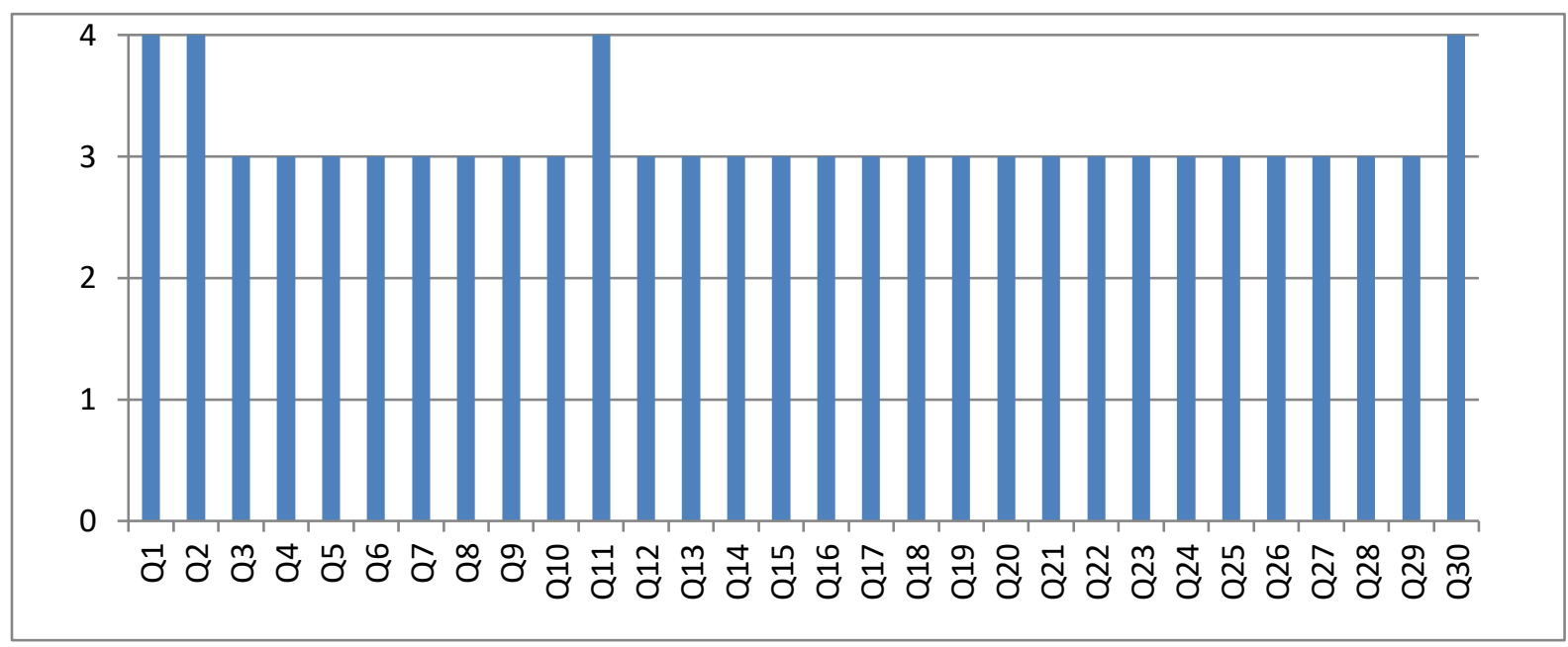

\section{Gambar 3. Diagram Hasil Review Ahli Materi}

Berdasarkan gambar 3 hasil review ahli materi dari penyajian 30 pernyataan diatas terdapat 4 pernyataan mendapat nilai 4 , dan 26 pernyataan mendapat nilai 3 . Dari nilai yang didapatkan multimedia tutorial bernilai positif dan layak untuk digunakan. Respon komentar saran dari ahli materi yakni, multimedia ini sangat bagus untuk membantu proses pembelajaran didalam/luar pembelajaran sekolah. Adapun saran dari ahli materi, sebagai berikut Gambar bumi sebaiknya divisualisasikan tampak seperti aslinya dan sistem navigasi dibuat tidak linier.

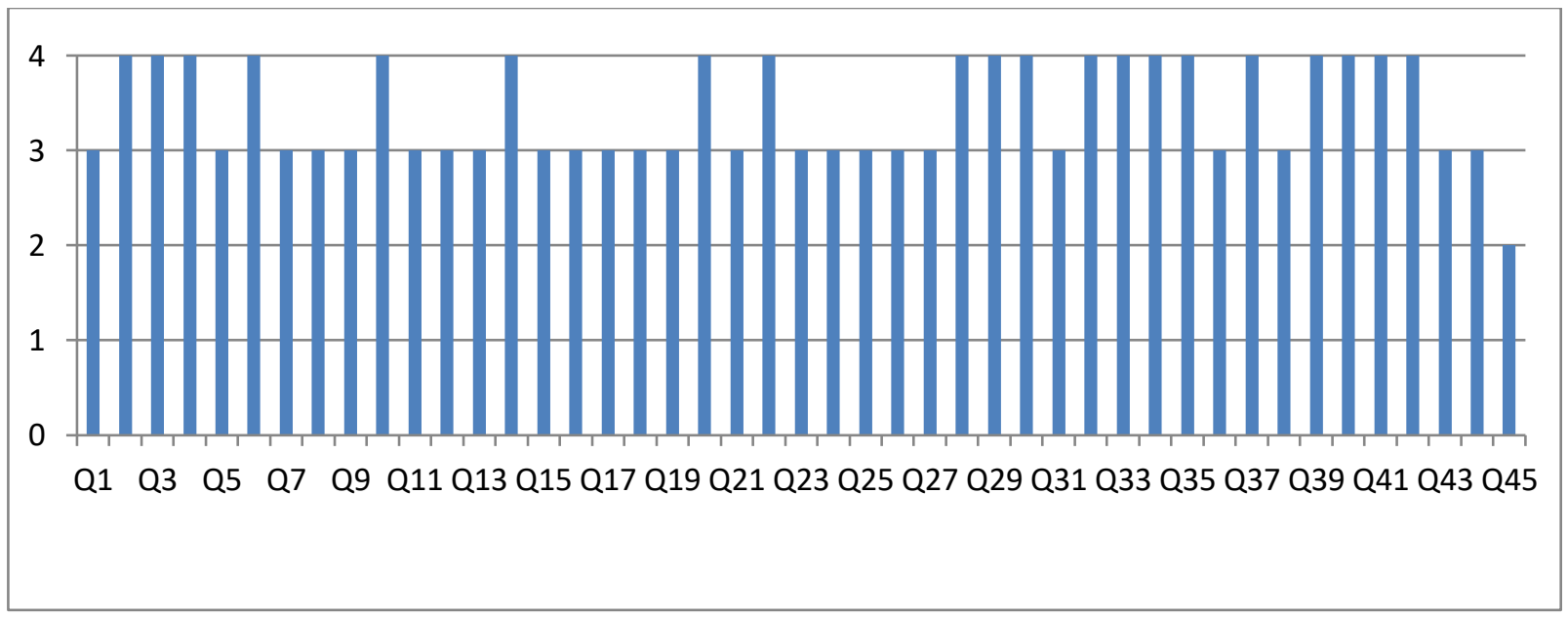

\section{Gambar 4. Diagram Hasil Review Ahli Media}

Berdasarkan gambar 4 hasil review ahli media dari penyajian 44 pernyataan diatas terdapat 19 pernyataan mendapat nilai 4, 24 pernyataan mendapat nilai 3 dan 1 pernyataan mendapat nilai 2 . Maka mayoritas nilai yang didapatkan 4 dan 3, sehingga multimedia tutorial bernilai positif dan layak untuk digunakan. Ahli media juga memberikan respon bahwa Secara umum media sudah bagus, menarik, sesuai dengan tujuan pembelajaran. Terdapat catatan dari Ahli media bahwa ada persoalan ketidakjelasan informasi pada petunjuk yang harus dijelaskan secara rinci agar pengguna paham dan konten dengan jumlah halaman lebih dari satu diberikan keterangan halaman (page). 


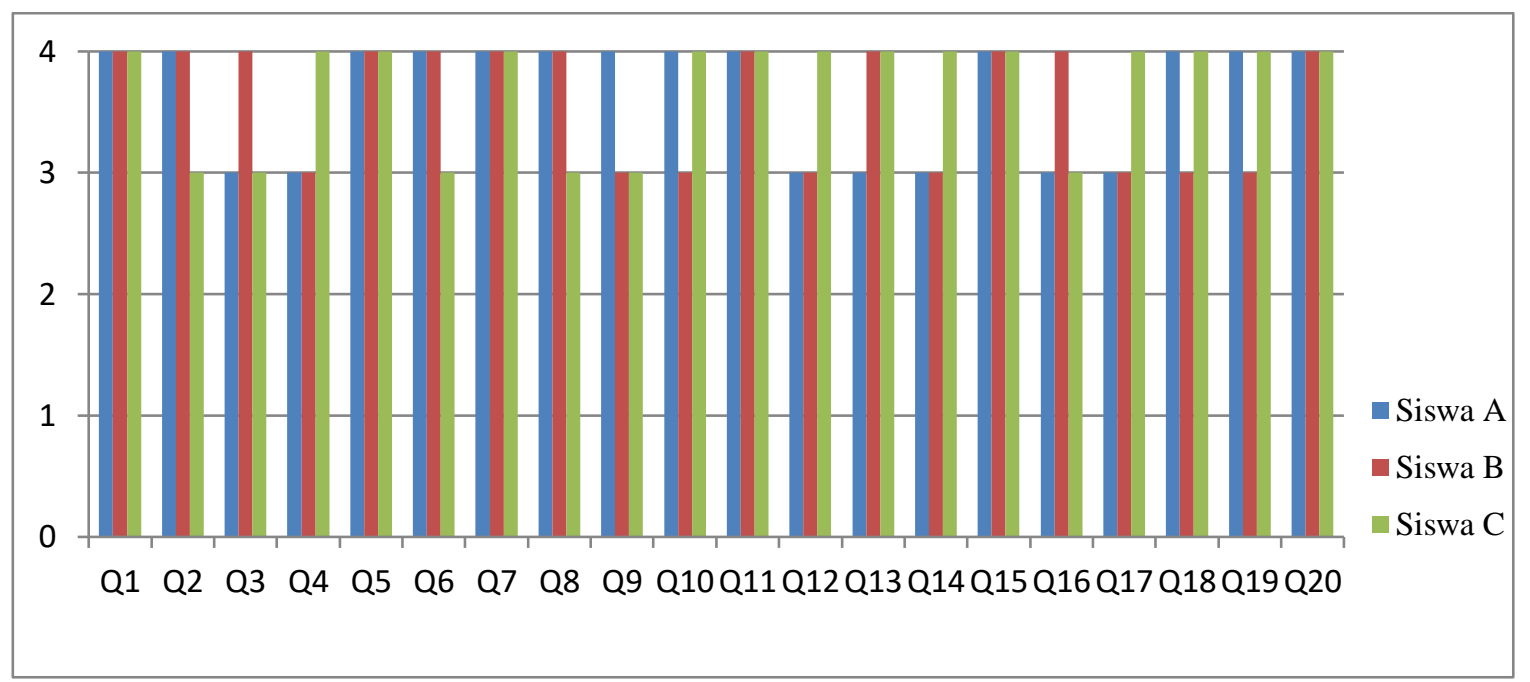

Gambar 5. Diagram Tanggapan Siswa

Berdasarkan gambar 5 hasil tanggapan 3 orang siswa dari penyajian 20 pernyataan diatas bahwa pada Siswa A sebanyak 13 pernyataan bernilai 4, dan 7 pernyataan mendapat nilai 3. Pada Siswa B 12 pernyataan bernilai 4 dan 8 pernyataan bernilai 3, sedangkan Siswa C 14 pernyataan bernilai 4 dan 6 pernyataan bernilai 3. Maka mayoritas nilai yang didapatkan 4 dan 3, sehingga multimedia tutorial bernilai positif dan layak untuk digunakan. Menggunakan multimedia tutorial lapisan bumi sebagai komplemen pembelajaran IPA membuat siswa menjadi mudah untuk memahami materi, meningkatkan semangat belajar dan inovatif serta dapat digunakan dalam proses belajar siswa di dalam maupun di luar kelas.

Uji coba produk multimedia tutorial dengan 3 siswa tersebut dengan harapan dapat memperkuat data yang bahwa produk dapat meningkatkan hasil belajar siswa. Hal tersebut dapat dilihat dari nilai pret-test dan post-tets siswa mendapatkan peningkatan nilai. Nilai pretest siswa mendapatkan nilai 40; 40; 47,6 dan nilai postest 87,$5 ; 80 ; 87,5$ nilai tersebut dapat dilihat bahwa multimedia yang berperan sebagai komplemen mampu meningkatkan hasil belajar siswa.

\section{PEMBAHASAN}

Motivasi sikap tanggung jawab siswa dalam pendidikan merupakan indikator keberhasilan suatu Multimedia memberikan kemudahan belajar bagi siswa dalam memahami materi lapisan bumi. Multimedia tutorial lapisan bumi telah melewati uji kelayakan oleh ahli media dan ahli materi yang memperoleh hasil positif atau layak digunakan dalam proses pembelajaran siswa. Multimedia tutorial juga dinyatakan sesuai dengan tujuan pembelajaran oleh ahli media. Ahli materi memberikan komentar bahwa produk ini sangat membantu belajar siswa dengan materi yang bersifat abstrak yang telah divisualisasikan menggunakan multimedia tutorial lapisan bumi. Menurut (Rusmiyati, 2014) siswa tidak perlu berpikir abstrak, dengan adanya fasilitas multimedia yang digunakan di kelas maupun di laboratorium. Multimedia tutorial terbukti mampu meningkatkan minat belajar siswa dalam menguasai materi secara lengkap dengan sumber belajar yang berbasis ICT sesuai tingkat kemampuan dan minatnya (Prayoga et al., 2016). Hal tersebut membuktikan bahwa model tutorial menunjukkan hasil positif jika digunakan sesuai prosedur (Mawarni,et al., 2017).

Hasil review ahli media didapatkan 45 pernyataan dengan nilai 4 dan 3, serta 1 pernyataan dengan nilai 2. Dari nilai yang didapatkan multimedia tutorial lapisan bumi bernilai positif dan layak untuk digunakan. Ahli media memberi catatan untuk menambahkan petunjuk penggunaan dengan jelas dan lebih rinci, memberi keterangan halaman di setiap tampian materi, dan mengecek kata-kata yang typo. Sedangkan review dari ahli materi didapatkan sejumlah 30 pernyataan dengan nilai 3, 4 pernyataan dengan nilai 4. Maka mayoritas nilai yang didapatkan dari 30 pernyataan adalah nilai 3 dan 4 , sehingga multimedia tutorial lapisan bumi bernilai positif dan layak untuk digunakan. Ahli media juga memberi 
saran supaya gambar bumi divisualisasikan nampak asli, dan sistem navigasi dibuat tidak linier. Berdasarkan hasil review yang didapatkan dari para ahli multimedia pembelajaran layak digunakan untuk pembelajaran. Hal ini didukung oleh hasil penelitian yang telah dilakukan oleh Viana (2013) bahwa multimedia interaktif model tutorial efektif dalam meningkatkan hasil belajar siswa dan diperoleh $87,50 \%$ siswa tuntas KKM. Seperti penelitian sebelumnya oleh Riasti (2016) dengan hitungan data yang diperoleh dari ahli media, ahli materi serta ujicoba siswa menyatakan bahwa media menarik dan layak untuk digunakan saat proses pembelajaran.

Uji coba produk multimedia tutorial di lapangan dapat meningkatkan hasil belajar siswa. Hal tersebut dapat dilihat dari nilai pretest dan postest siswa mendapatkan peningkatan nilai. Berikut nilai pretest siswa mendapatkan nilai 40; 40;47,6 dan nilai postest 87,$5 ; 80 ; 87,5$ nilai tersebut dapat dilihat bahwa multimedia yang berperan sebagai komplemen mampu meningkatkan hasil belajar siswa. Para siswa juga diminta mengisi lembar tanggapan siswa terkait media tutorial yang telah diuji cobakan. Hasil yang didapat dari 3 orang siswa dari penyajian 20 pernyataan bahwa pada Siswa A sebanyak 13 pernyataan bernilai 4, dan 7 pernyataan mendapat nilai 3. Pada Siswa B 12 pernyataan bernilai 4 dan 8 pernyataan bernilai 3, sedangkan Siswa C 14 pernyataan bernilai 4 dan 6 pernyataan bernilai 3. Maka mayoritas nilai yang didapatkan 4 dan 3, sehingga multimedia tutorial bernilai positif dan layak untuk digunakan. Menggunakan multimedia tutorial lapisan bumi sebagai komplemen pembelajaran IPA membuat siswa menjadi mudah untuk memahami materi, meningkatkan semangat belajar dan inovatif serta dapat digunakan dalam proses belajar siswa didalam maupun diluar kelas. Hal teserbut selaras dengan penelitian (Meitantiwi, et al ,2015) Multimedia tutorial memiliki efektivitas yang baik untuk pembelajaran kimia dengan adanya perbedaan hasil tes yang lebih baik pada kelas perlakuan dibandingkan dengan kelas tanpa perlakuan.

Multimedia tutorial lapisan bumi ini berperan sebagai komplemen pembelajaran yang digunakan untuk membantu kelompok siswa yang berbeda-beda (fast learner and slow learner) dalam memahami pelajaran yang diberikan oleh guru mata pelajaran. Multimedia tutorial di desain prosedural untuk siswa mempelajari materi secara tuntas (mastery). Sehingga jika siswa belum memahami materi yang dipelajari maka akan mengulang materi tersebut untuk bisa lanjut ke tahap selanjutnya. Multimedia tutorial yang dikembangkan memiliki fitur peta konsep yang membedakan dengan multimedia tutorial lainnya. Fitur peta konsep digunakan untuk alat evaluasi siswa dengan pendekatan belajar yang diharapkan mampu untuk meningkatkan motivasi dan antusiasme belajar siswa sehingga tercapainya tujuan pembelajaran. Fitur peta konsep atau yang bisa disebut mind mapping, dalam penerapannya yang dikombinasi dengan multimedia dalam pembelajaran dapat meningkatkan aktivitas siswa (Rahmawanto, 2018). Dengan fitur peta konsep membantu siswa dalam mempemudah mengikuti proses pembelajaran, serta penyerapan materi pelajaran di kelas (Luki, et al, 2014). Sejalan dengan hasil penelitian oleh (Noviasari, Legowo, \& Lilik, 2015) yang menyatakan bahwa metode belajar menggunakan mind map efektif untuk meningkatkan kreativitas pada siswa SMP. Hasil penelitian tersebut mendukung bahwa tujuan penggunaan mind map adalah untuk meningkatkan kreativitas siswa.

Program multimedia tutorial bisa dimanfaatkan sebagai strategi dalam pembelajaran mandiri menggunakan strategi setiap siswa harus menggunakan satu komputer, dimana siswa bisa belajar dimanapun menggunakan program multimedia tutorial apabila terdapat sarana seperti komputer dan lainya. Apabila bisa dimanfaatkan sebagai strategi belajar mandiri, multimedia tutorial tersebut juga mampu digunakan dalam kegiatan belajar di kelas, dengan pembelajaran yang harus dilakukan di laboratorium komputer (Istiqlal, 2017). Produk multimedia tutorial ini berbentuk format .exe (executable file) yang dikembangkan dengan menggunakan software Lectora inspire versi 17, didukung software Adobe Flash CS 6, Adobe Photoshop CS 6, Corel Draw X8.

Multimedia tutorial lapisan bumi memiliki berapa keunggulan diantaranya: multimedia tutorial lapisan bumi sebagai komplemen pembelajaran IPA kelas VII di MTs Negeri 2 Nganjuk layak 
digunakan dalam pembelajaran; multimedia tutorial lapisan bumi memuat tulisan, gambar, audio, dan video untuk menunjang bahan ajar; multimedia tutorial lapisan bumi mampu untuk memvisualisasikan materi yang bersifat abstrak sehingga mudah untuk memahami materi; dapat digunakan saat proses pembelajaran dikelas maupun diluar kelas; menjadi pelengkap bahan ajar untuk kelompok belajar siswa yang berbeda (slow learner/fast learner); memiliki fitur peta konsep sebagai evaluasi belajar siswa. Hal tersebut diperkuat dengan hasil penelitian dari I Gede Malik Sutama Gama tahun 2016, memberikan hasil layak berada di kualifikasi sangat baik serta mampu untuk meningkatkan hasil belajar siswa.

Multimedia ini dikembangkan sebagai komplemen (pelengkap) pada mata pelajaran IPA materi lapisan bumi menyajikan petunjuk penggunaan yang berisi cara penggunaan produk. Petunjuk berfungsi untuk memudahkan pengguna dalam menggunakan produk yang dikembangkan, agar hasil produk multimedia tutorial ini dapat bermanfaat dalam proses pembelajaran. Pada pembelajaran selanjutnya dapat menggunakan media pembelajaran ini sehingga siswa memperoleh sumber belajar yang maksimal. Sifat bahan ajar komplemen ini adalah opsional, sehingga pengguna bebas memilih menggunakan media pembelajaran ini atau tidak dalam melengkapi materi dalam proses pembelajaran. Multimedia tutorial lapisan bumi yang dikembangkan hanyalah tambahan, tidak dapat menggantikan bahan ajar utama. Begitupula pengembangan dari Umroh et al. (2019) penelitian tersebut dinyatakan layak setelah melalui uji validitas dan mampu untuk memotivasi siswa.

Multimedia yang berperan sebagai bersifat opsional ini dalam proses pembelajaran yang mampu menambah motivasi dan meningkatkan hasil dari belajar siswa. Siswa akan menganggap lebih tertarik dan percaya diri dalam proses belajar, sehingga hasil belajar siswa yang dapatkan bertambah sesuai dengan harapan siswa masing-masing. Hal tersebut dibenarkan dengan penelitian yang sudah dilakukan oleh (Wardani et al., 2019) dengan judul "Pengembangan Multimedia Tutorial Mata Pelajaran IPA Pokok Bahasan Sistem Tata Surya Kelas VII MTS Raudlatul Ulum Karangploso" multimedia tutorial ini merupakan salah satu solusi dalam soal media pembelajaran.

\section{SIMPULAN}

Multimedia Tutorial Lapisan Bumi sebagai Komplemen Pembelajaran IPA di MTs Negeri 2 Nganjuk, dengan menggunakan multimedia pembelajaran dikelas menjadi lebih menarik dan antusias, hal tersebut tentunya memberikan dampak positif terkait solusi permasalahan selama pembelajaran IPA. Multimedia tutorial lapisan bumi sangat mudah digunakan dan dapat diulang-ulang oleh siswa meski tidak berada di sekolah. Hasil angket review ahli materi dan ahli media pada multimedia tutorial lapisan bumi mendapatkan respon positif serta layak digunakan dengan perannya sebagai komplemen pembelajaran. Pada uji kelompok kecil juga menunjukkan hasil layak digunakan, meskipun terdapat beberapa komentar dan saran dari para ahli. Selama penggunaan multimedia tutorial siswa sangat antusias dan senang dalam pengoperasianya. Dengan demikian multimedia tutorial dapat digunakan sebagai pelengkap pembelajaran konvensional di MTs Negeri 2 Nganjuk.

\section{DAFTAR RUJUKAN}

Anas A. M., Soepriyanto, Y., \& Susilaningsih. (2019). Pengembangan Multimedia Tutorial Topologi Jaringan Untuk SMK Kelas X Teknik Komputer Dan Jaringan. JKTP Volume 1, Nlomor 4, Desember 2018, 307-314. http://journal2.um.ac.id/index.php/jktp/article/view/6916/3859.

Alessi, S. M., \& Trollip, S. R. (2001). Multimedia for Learning Methods and Development 3rd. Massachusetts: Pearson Educational Company.

Arends, R. I. (1997). Classroom Instruction \& Management. New York: The Mc Graw-Hill Companies.

Asan, A (2007). Concept mapping in Science Class: A Study of fifth grade students. Jurnal Educational Technology \& Society, 10 (1), 186-195 
Capuno, R., Revalde, H., Etcuban, J. O., Aventuna, M., Medio, G., \& Demeterio, R. A. (2019). Facilitating Learning Mathematics Through the Use of Instructional Media. International Electronic Journal of Mathematics Education, 15(1), 677-688. https://doi.org/10.29333/iejme/5785

Hilbert, T. S., \& Renk1, A. (2009). Learning how to use a computer-based-concept-mapping tool : self explaining examples help. Computers in Human Behavior, 25, 267-274

Gama, I. G. B. S., Mahadewi, L. P. P., \& Jampel, I. N. (2016). Pengembangan Multimedia Tutorial Interaktif Sumber Daya Alam dan Teknologi pada Mata Pelajaran IPA Kelas IV di SDN 3 Banyuasri. Jurnal EDUTECH, 6(3), 1-10.

Istiqlal, M. (2017). Pengembangan Multimedia Interaktif Dalam Pembelajaran Matematika. VIPMat, 2(1). hlttps://doi.org/10.26877/jipmat.v2i1.1480

Juarez Collazo, N. A., Elen, J., \& Clarebout, C. (2015). The multiple effect of combine tools in computer baseld learning environments. Computer in Human Behavior, 51A, 82-95.

Kadir. (2004). Efektivitas Strategi Peta Konsep Dalam Pembelajaran Sains Dan Matematika. Jurnal Pendidikan dan Kebudayaan 51:10.

Kastawaningtyas, A., \& Martini. (2017). Peningkatan Keterampilan Proses Sains Siswa Melalui Model Experiential Learning pada Materi Pencemaran Lingkungan. Jurnal Penelitian Pendidikan IPA, 46.

Khoerunisa, M. (2014). Pembelajaran Bioteknologi Berbasis Multimedia Tutorial Untuk Meningkatkan Hasil Belajar Siswa Kelas IX di SMPN 8 Cirebon. Jurnal Pendidikan Sains.

Lee. W.W \& Owens. D L. (2004). Multimedia-Based Instructional Design, (2nd Ed.) SanFrancisco: Pffeiffer

Luki Y., Sofyan A., Agung S. (2014). Pemanfaatan Peta Konsep (Concept Mapping) Untuk Meningkatkan Pemahaman Siswa Tentang Konsep Senyawa Hidrokarbon. Jurnal EDUSAINS IVolume VI Nomor 01 Tahun 2014, 8 - 8

Mawarni, Sella \& Muhtadi, Ali. (2017). Pengembangan Digital Book Interaktif Mata Kuliah Pengembangan Multimedia Pembelajaran Interaktif Untuk Mahasiswa Teknologi Pendidikan. Jurnal Inovasi Teknologi Pendidikan Vol 4 (1). 84-96

Meintantiwi, Erna Yustin (2015). Pengembangan Multimedia Pembelajaran Tutorial Menggunakan Software Macromedia Flash Pada Materi Sifat Keperiodikan Unsur Untuk Pembelajaran Kimia Kelas X MIA SMA. Jurnal Universitas Sebelas Maret.

Nikolawatin, Z., Setyosari, P., \& Ulfa S. (2019). Pengembangan Media Tutorial Bahasa Isyarat Untuk Siswa Tunarungu SLB BC Kepanjen. JINOTEP (Jurnal Inovasi dan Teknologi Pembelajaran): Kajian dan Riset Dalam Teknologi Pembelajaran Vol 6, No 1, October 2019, Hal. 15-22.

Noviasari, K., Legowo, E., \& Lilik, S. (2015). Keefektifan Mind Map untuk Meningkatkan Kreativitas Peserta Didik SMP. Consilium: Jurnal Program Studi Bimbingan Dan Konseling, 3(1).

Prayoga, G. S., Sudarma, I. K., \& Tegeh, I. M. (2016). Pengembangan Multimedia Interaktif Model Tutorial Pada Mata Pelajaran PKN Kelas VIII Semester Genap Di SMP Negeri 16 SingaRaja Tahun Pelajaran 2015/2016. Jurnal Teknologi Pendidikan Universitas Pendidikan Ganesha, 5(2).

Rahmawanto, Roni. (2018). Penggunaan Teknik Mind Map Berbasis Multimedia Presentasi Untuk Meningkatkan Aktivitas Dan prestasi Belajar Siswa. Jurnal Kajian Teori dan Praktik Kependidikan. Volume 3 Nomor\1 Juni 2018 hlm 83-90. http://journal2.um.ac.id/index.php/jktpk. 
Riasti, M.F., Suyatna, A., \& Wahyudi, I.(2016). Pengembangan Media Interaktif Model Tutorial Pada Materi Impuls Dan Momentum. Jurnal Pembelajaran Fisika. 4(1).

Rusmiyati, I. (2014). Penggunaan Multimedia Dalam Pembelajaran Bahasa Sastra. Jurnal Pendididkan dan Teknologi Pembelajaran, 171 - 184.

Suminar D., (2019). Penerapan Teknologi Sebagai Media Pembelajaran Pada Mata Pelajaran Sosiologi. Jurnal Pendidikan FKIP Universitas Sultan Ageng Tirtayasa Vol. 2, No.1, 2019, hal. 774-783

Suyono \& Hariyanto. (2014). Belajar dan Pembelajaran: Teori dan Konsep Dasar. Bandung: Remaja Rosdakarya.

Umroh, N. S., Adi, E. P., \& Ulfa, S. (2019). Multimedia Tutorial Untuk Menumbuhkan Minat Baca Anak Adhd (Attention Deficit Hyperactivity Disorder). Jurnal Kajian Teknologi Pendidikan, 2(1), 45-52. http://journal2.um.ac.id/index.php/jktp/article/view/7628

Wardani, S. K., Setyosari, P., \& Husna, A. (2019). Pengembangan Multimedia Tutorial Mata Pelajaran IPA Pokok Bahasan Sistem Tata Surya Kelas VII MTS Raudlatul Ulum. Jurnal Kajian Teknologi Pendidikan, 2(1), 23-29.

http://journal2.um.ac.id/index.php/jktp/article/view/7370 